\title{
Changes in the soft-tissue thickness of the claw sole in Holstein heifers around calving
}

\author{
K. Bach, ${ }^{1 *}$ (1) S. S. Nielsen, ${ }^{2}$ (1) and N. Capion ${ }^{1}$ () \\ ${ }^{1}$ Department of Veterinary Clinical Sciences, University of Copenhagen, Højbakkegård Allé 5, Building 8-64, 2630 Taastrup, Denmark \\ ${ }^{2}$ Department of Veterinary and Animal Sciences, University of Copenhagen, Grønnegårdsvej 8, 1870 Frederiksberg C, Denmark
}

\begin{abstract}
Claw horn disruption lesions are a common cause of lameness in dairy cattle. It is commonly agreed that they develop due to excessive pressure from the distal phalanx on the horn-producing tissue in the sole. The distal phalanx is supported by the suspensory apparatus, a large proportion of which is made up of connective tissue. It has been hypothesized that increased laxity of the connective tissue due to hormonal changes around calving may lead to decreased support of the distal phalanx, resulting in a sinking of the bone and increased pressure on the horn-producing tissue. In this longitudinal study, our first objective was to determine whether the thickness of the soft tissue related to the claw sole (the combined depth of the digital cushion and corium; soft-tissue thickness, STT) in the weightbearing hind claws of live heifers changed around calving (the period from approximately $3 \mathrm{wk}$ before calving to 2 wk after calving). Our second objective was to evaluate the relationship between the body condition score (BCS) of recruited heifers and the STT estimates we obtained. We measured STT (defined as the distance between the distal phalanx and the sole horn) in the apex and the posterior part of the sole of the hind claws of 34 Holstein heifers 4 times over 3 to 4 wk around calving. We determined STT by ultrasonographic measurements through the sole horn on weightbearing claws. The overall mean STT at site 1 was 3.3 $\mathrm{mm}$ [minimum-maximum (min-max): 1.8 to $5.2 \mathrm{~mm}$ ], and the mean at site 2 was $3.7 \mathrm{~mm}$ (min-max: 2.2 to 5.8). The overall mean STT was thickest in the first examination before calving [site 1: $3.4 \mathrm{~mm}$ (min-max: 1.9 to 4.7 ); site 2 : $4.1 \mathrm{~mm}$ (min-max: 2.7 to 5.8 )] and thinnest at site 1 in the second examination after calving (3.2 mm, min-max: 1.8 to 5.2$)$ and at site 2 at the
\end{abstract}

Received June 26, 2020.

Accepted December 14, 2020.

*Corresponding author: kurtbach@gmail.com first examination after calving $(3.5 \mathrm{~mm}$, min-max: 2.2 to 5.0). We observed an average reduction in STT of $-0.2 \mathrm{~mm}$ (min-max: 0.8 to $-0.9 \mathrm{~mm}$ ) at site 1 during the study period, but we did not observe this reduction in all animals. At site 2, we found an average reduction in STT of $-0.6 \mathrm{~mm}$ (min-max: 0.8 to $-1.3 \mathrm{~mm}$ ) from $10 \mathrm{~d}$ before calving to $5 \mathrm{~d}$ after calving, corresponding to a decrease of approximately $15 \%$ (min-max: 0 to $31 \%$ ). We suggest that this reduction was caused by a rotation of the distal phalanx toward the posterior part of the sole horn in the weeks around calving. During the same period, heifer BCS decreased between 0.25 and 0.5 increments in the BCS scale, but we found no correlation between BCS and STT. However, the heifers experienced many changes related to management, feeding, and time budget during the study period, and the rotation of the distal phalanx and reduction of the STT might be explained not only by calving but also by other factors that affect heifers and their claws during the transition period.

Key words: dairy heifer, digital cushion, calving, ultrasound

\section{INTRODUCTION}

Lameness in dairy cows is a prevalent and global problem (Thomsen et al., 2012; von Keyserlingk et al., 2012; Fabian et al., 2014) that affects the welfare of the animals (Whay et al., 2003; Bruijnis et al., 2012) and results in reduced herd profitability due to lower milk production (Warnick et al., 2001; Ettema et al., 2007), decreased fertility (Garbarino et al., 2004; Bicalho et al., 2007), and early culling of lame cows (Booth et al., 2004). The prevalence of lameness found in studies from Denmark, Canada and the United States, and New Zealand ranged from 1.2 to $54.8 \%$ (Thomsen et al., 2012; von Keyserlingk et al., 2012; Fabian et al., 2014).

Lameness is often a clinical sign of claw horn disruption lesions (CHDL), which affect the hind claws in particular (Vermunt and Greenough, 1996; Capion et al., 2008). It is generally agreed that many lesions de- 
velop as a consequence of changes in the integrity of the suspensory apparatus and supporting tissues, leading to a displacement of the distal phalanx and increased pressure on the horn-producing tissue in the sole. This results in contusions and ultimately disruption of horn production (Ossent and Lischer, 1998; Tarlton et al., 2002; Räber et al., 2004). Several risk factors - including the type of flooring (Bergsten et al., 2015), heat stress (Cook et al., 2007), standing time, and barn design (Cook et al., 2004a) - have been associated with the development of CHDL. Lameness and CHDL are most prevalent 2 to 4 mo after calving (Bergsten and Herlin, 1996; Green et al., 2002; Lim et al., 2015), suggesting that parturition and lactation play a part in their pathogenesis.

Several studies have linked the thickness of the sole's soft tissue to the development of CHDL (Bicalho et al., 2009; Machado et al., 2010; Newsome et al., 2017a,b). The soft tissue was thinner in claws from the cadavers of culled lame cows compared with nonlame cows (Lischer et al., 2002). The thickness of the digital cushion measured using ultrasonography on elevated claws has also been associated with lameness and CHDL in a cross-sectional study (Bicalho et al., 2009), where the mean soft-tissue thickness (STT) from 501 cows was categorized into 4 quartiles, from lowest to highest. The authors found CHDL in 24.4 and $28.1 \%$ of cows with low STT in the first and second quartiles, respectively, and they found CHDL in 14.5 and $8.6 \%$ of cows in the third and fourth quartiles. They concluded that the risk of developing CHDL was significantly higher in cows with a thin STT $(8.8 \mathrm{~mm}$; 95\% confidence interval 8.6$9.0 \mathrm{~mm}$ ) compared to cows with a thick STT $(9.5 \mathrm{~mm}$; 95\% confidence interval $9.1-9.9 \mathrm{~mm}$ ). The same study reported a positive association between the thickness of the cushion and BCS, suggesting that fat is mobilized from the cushion when the cow loses weight. Bicalho et al. (2009) hypothesized that low BCS was a risk factor for the development of CHDL, and this hypothesis has been supported by 3 longitudinal studies (Green et al., 2014; Lim et al., 2015; Randall et al., 2015). To demonstrate the relationship between change in BCS and digital cushion thickness, Newsome et al. (2017a) took repeated ultrasonographic measurements of both the digital cushion on elevated claws and back-fat thickness from before calving to late lactation. Back-fat thickness decreased during lactation, reaching a minimum at $17 \mathrm{wk}$ after calving, but the digital cushion thickness distal to the flexor tuberosity was thinnest at $1 \mathrm{wk}$ after calving. This finding suggested that BCS was not the only factor to affect the thickness of the digital cushion, and it highlighted the importance of the period around calving.
The suspensory connective tissue around the distal phalanx is softened, likely due to the influence of hormones stimulating a relaxation of the pelvis around calving (Tarlton et al., 2002; Knott et al., 2007). Tarlton et al. (2002) demonstrated decreased strength in the connective tissue supporting the distal phalanx in the months after calving by assessing the biomechanical properties of the claw horn wall of nonpregnant and pregnant heifers that had been euthanized in different weeks relative to calving. They suggested that this could lead to a sinking of the distal phalanx and increased pressure on the sole horn. We aimed to assess this theory using live heifers and weight-bearing claws. Previous studies have used direct ultrasound on elevated claws or cadaver feet. To date, no reports have been published of the effect of weight-bearing on changes in the claws. Our objective was to assess whether the STT between the distal phalanx and the inside margin of the sole horn changed in the weeks around calving. We hypothesized that the thickness would decrease a few days before calving.

\section{MATERIALS AND METHODS}

\section{Study Herd}

We performed a prospective longitudinal study in a commercial dairy herd with 740 Holstein cows in the western part of Jutland, Denmark. The herd was selected based on the owner's willingness to separate heifers and fresh cows every week during the study period from June 1 to August 30, 2015, and having access to a stand-up trimming chute on the farm. The herd size ensured that enough heifers calved every week to select and enroll 5 new animals for every week of the study period. The animals were moved to different housing environments in the months around parturition (Table 1).

\section{Animals}

We examined the hind claws of Holstein heifers that calved during the study period. The term "heifer" refers to a cow that has not had any offspring, but will be used to describe the animals before and after parturition in this study. We retrieved information about the expected calving date and the actual date of calving from the Danish Cattle Database (SEGES, Aarhus N, Denmark).

Following standard practice on the farm, the heifers' hooves were trimmed by a certified claw trimmer 1 month before the estimated date of calving. The claws were trimmed according to the Danish method 
(Fritzböger and Smedegaard, 1962) using an electric angle grinder, and any claw disorder was recorded and uploaded to the Danish Cattle Database. If a heifer had a severe claw disorder (e.g., sole ulcer, white line disease, toe necrosis, digital dermatitis), she was excluded from the study. The quality of recordings made by the claw trimmer was evaluated before the study period by one of the authors (KB) through observation and discussions.

Our intention was to examine the enrolled heifers 4 times at 1-wk intervals: twice before calving and twice after calving. Five heifers were enrolled in the study every week, resulting in a maximum of 20 animals to evaluate on each examination day. Before each examination, the heifers were evaluated for signs of lameness using the 3-point scale described in the Welfare Quality protocol (Welfare Quality, 2009). Heifers that became lame (score $>0$ ) or were diagnosed with a disease expected to interfere with the result were excluded from the study.

The heifers in the study were not subjected to any invasive examination methods and were on the platform in the trimming chute for only a short period ( 5 min). Ethical approval was therefore not required, in accordance with Danish standards.

\section{Ultrasonographic Measurement}

The first examination was conducted 3 to 4 wk before the expected calving date in a stand-up trimming chute (KVK, Esbjerg, Denmark); the heifers stood on a platform with their hind claws in a customized polyethylene tub, as described by Bach et al. (2019). The heifers were fixed only in the headlock of the chute; and a belly band was not used. We did not trim claws for the entire period, and it was not necessary to achieve good contact between the sole and the bottom of the tub.
The tub was filled with water to a depth of approximately $5 \mathrm{~cm}$. We ensured that the heifers were bearing weight on both hind legs through visual inspection. The transducer was placed under the tub, and ultrasonographic measurement was performed through the bottom of the tub and the sole horn using a linear transducer (48 $\mathrm{mm}$ long and $14 \mathrm{~mm}$ wide; GE i739LRS) with a bandwidth of 3.5 to $10.0 \mathrm{MHz}$ connected to a GE Loqic e BT11 portable scanner (GE Healthcare, Chicago, IL). The scans were performed in B-mode at 6 $\mathrm{MHz}$, with medium gain at a depth of $4 \mathrm{~cm}$. A ProtexClassic condom (House of Denmark, Vejle, Denmark) filled with a small amount of ultrasound gel was used to protect the transducer. To ensure optimal contact between the transducer and the bottom of the tub, an ample amount of ultrasound gel was applied to the transducer/condom.

Two areas of the sole horn were examined for each hind claw: in the apex of the claw (site 1, Figure 1) and beneath the vertex of the tuberculum flexorum of the distal phalanx (site 2, Figure 1). At site 1, the apex of the distal phalanx and the internal margin of the sole horn were identified on the screen and the transducer was moved slightly from side to side. When the shortest distance between the sole horn and the apex of the distal phalanx was identified, a video loop including the last $10 \mathrm{~s}$ of the scan was saved on the scanner's hard drive for evaluation. Likewise at site 2 , the tuberculum flexorum of the distal phalanx and the internal margin of the sole horn were identified, and the video loop was saved when the shortest distance between these structures was identified. Information on cow identification, date of examination, leg, claw, and site was recorded for each sequence. The second examination was conducted 1 wk after the first. The third examination was conducted at the first visit after calving, and the fourth examination was conducted 1 wk after the third. The number of days between the

Table 1. Housing and management of heifers at different stages $^{1}$

\begin{tabular}{llll}
\hline & & \multicolumn{2}{c}{ Stage } \\
\cline { 2 - 4 } Variable & $\begin{array}{l}16 \text { mo to } 1 \text { mo before } \\
\text { parturition }\end{array}$ & $\begin{array}{l}1 \text { mo before parturition } \\
\text { to calving }\end{array}$ & First month after calving \\
\hline Flooring & Solid concrete & Concrete slats & Slatted floor with rubber on top \\
Bedding & Cubicles with mattress & Cubicles with rubber mats & Cubicles with mattress \\
Floor cleaning & Automatic scraper & Manual once a day & Automatic scraper \\
Feed & TMR, special heifer ration & TMR, dry cow ration & TMR, lactating cow ration \\
Milking frequency & - & - & 31.2 \\
Mean daily milk yield, $\mathrm{kg}$ & - & - & 32.9 \\
Cows in first parity & - & - & \\
Older cows & - & & \\
\hline
\end{tabular}

${ }^{1}$ The average age at first calving was $23.7 \mathrm{mo}(\min -\max 21.5-27.6 \mathrm{mo})$.

${ }^{2}$ All rations were based on a combination of corn and grass silage, soy and canola protein, whole grain barley, straw, and minerals.

${ }^{3}$ Conventional milking in herringbone milking parlor. 


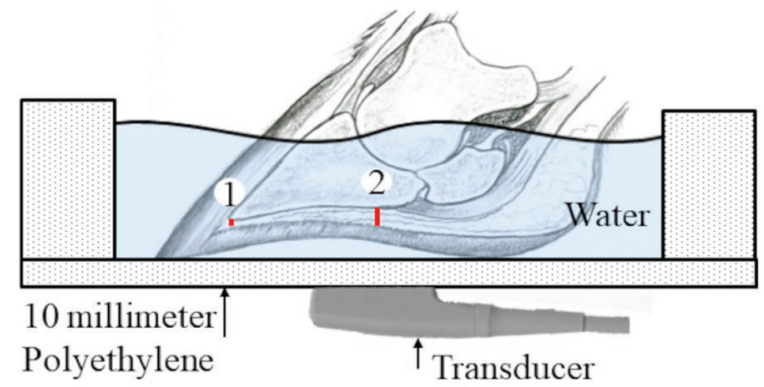

Figure 1. Depiction of how the heifers stood with their hind claws in a tub filled with $5 \mathrm{~cm}$ of water to avoid air between the bottom of the tub and the sole horn. Scans were performed through the polyethylene base of the tub (10 $\mathrm{mm}$ thick). The 2 red lines mark site 1 at the apex of the sole and site 2 in the posterior part of the sole where the measurements were taken. The lines also indicate the distance measured.

second and third examinations varied depending on the date of calving.

\section{Evaluation of the Ultrasonographic Imaging}

The video sequences were evaluated visually. The video was paused when the distance between the distal phalanx and the internal margin of the sole horn was shortest, and STT was determined on the image using the measuring software on the portable scanner. The measurements were recorded in millimeters, with a precision of $0.1 \mathrm{~mm}$.

\section{Body Condition}

On each examination day, the body condition of the heifers was scored by a master's student using a categorical scale of 1 to 5 with 0.25 increments (Edmonson et al., 1989). The intrarater reliability of BCS was evaluated using repeated blinded observations for 57 cows in the herd.

\section{Statistical Analysis}

Data were analyzed using the tidyverse (Wickham et al., 2019) and nlme (v3.1-140; Pinheiro et al., 2019) packages for $\mathrm{R}$ version 3.6.1 (www.r-project.org). The mean STT at sites 1 and 2 for each cow were plotted as a function of days from calving, and a smoothed line for all measurements was added to the plots, where the variable "days from calving" was calculated as the number of days between calving and examination, and was used as an effect of time.

Variations in STT between the left and right leg and the inner and outer claw were measured at the 2 specific areas of the sole horn. A linear mixed model was used to assess STT at sites 1 and 2 separately using the lme function; time (days from calving), claw (lateral and medial), and leg (left and right) were used as explanatory variables, and cow was used as a random effect to take into account the repeated measurements for each animal. The model assumptions, including residuals being independent and identically distributed as normal, were assessed via visual inspection of the residuals from Q-Q plots. A threshold of $P<0.05$ was used to determine statistical significance.

To evaluate whether a change in BCS around calving had an effect on STT, we plotted the change in STT at site 2 from before to after calving as a function of a change in BCS. We calculated the mean of the 2 BCS scores before calving (BCS 1 and 2) and the 2 scores after calving (BCS 3 and 4) for each cow, and calculated the change in BCS as the difference between the 2 means. Likewise, a change in STT was calculated as the difference between the mean STT from all 4 claws measured before calving (STT 1 and 2) and after (STT 3 and 4) calving. We used only measurements from site 2, because STT included the digital cushion, which was a structure likely to be affected by a change in BCS (Bicalho et al., 2009). The correlation between the change in BCS and STT was analyzed using linear regression with the $\operatorname{lm}()$ function.

Intrarater reliability was evaluated by calculating a Cohen's $\kappa$ value for the agreement between the repeated BCS given by the master's student.

\section{RESULTS}

\section{Descriptive Statistics}

Five heifers were excluded during the study period: 1 because of poor quality of the scanning images, 1 died from sepsis after calving, 1 was treated for interdigital phlegmon, 1 fell in the milking parlor, and 1 did not calve during the study period. This left a total of 34 Holstein heifers in the study. One heifer calved earlier than expected; she was examined only once before calving and twice after calving, but remained in the study. We followed the protocol for the remaining 33 heifers because they calved during the period and were all examined twice before and twice after calving, with an interval of 1 wk between the first 2 and the second 2 examinations. Examination of each heifer consisted of 8 ultrasonographic measurements in the 4 hind claws. 
Table 2. Descriptive results for soft tissue thickness (STT) and BCS ${ }^{1}$

\begin{tabular}{|c|c|c|c|c|}
\hline \multirow[b]{2}{*}{ Variable } & \multicolumn{4}{|c|}{$\mathrm{Scan}^{2}$} \\
\hline & -2 & -1 & 1 & 2 \\
\hline Days from calving (range) & $-14(-26$ to -5$)$ & $-7(-17$ to 0$)$ & $4(0$ to 10$)$ & $11(7$ to 17$)$ \\
\hline \multicolumn{5}{|l|}{ STT } \\
\hline Claws, $\mathrm{n}$ & 132 & 136 & 136 & 136 \\
\hline Mean STT, site 1 (95\% CI) & $3.4(3.3-3.5)$ & $3.3(3.2-3.4)$ & $3.3(3.2-3.4)$ & $3.2(3.1-3.3)$ \\
\hline Mean STT, site $2(95 \%$ CI $)$ & $4.1(4.0-4.2)$ & $3.9(3.8-4.0)$ & $3.5(3.4-3.6)$ & $3.5(3.4-3.6)$ \\
\hline \multicolumn{5}{|l|}{ BCS } \\
\hline Cows, $\mathrm{n}$ & 33 & 34 & 34 & 34 \\
\hline Mean BCS & 3.65 & 3.58 & 3.44 & 3.31 \\
\hline Median BCS & 3.75 & 3.5 & 3.5 & 3.25 \\
\hline
\end{tabular}

${ }^{1}$ STT was measured between the distal phalanx and the sole horn in Holstein heifers $(\mathrm{mm})$. Site 1 was at the apex of the sole horn, and site 2 was the posterior part of the sole horn. BCS were recorded at each examination.

${ }^{2}$ Scan -2 was the first scan before calving, and -1 was the second. Scans 1 and 2 were the first and second scans after calving, respectively.

We carried out 1,080 ultrasonographic measurements on the 34 heifers. The number of examinations, mean days from calving at each examination, and mean STT measured at each site of the claw sole are shown in Table 2. The change in STT at sites 1 and 2 as a function of days from calving is illustrated in Figures 2 and 3 , respectively. We found considerable variation in STT between heifers, as well as in change over time.

At site 1 (Figure 2), the smoothed line shows only a minor decrease in STT over the study period, with an average reduction in STT of $0.2 \mathrm{~mm}$ [standard error

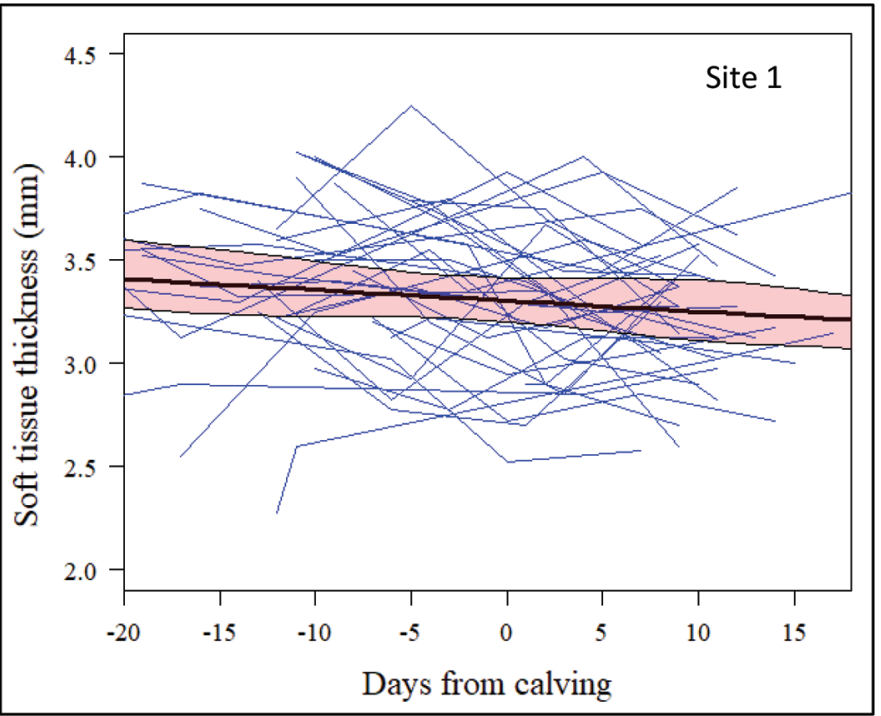

Figure 2. Changes in the mean soft-tissue thickness of all 4 hind digits from 34 Holstein heifers in the days around calving at site 1 , the apex of the sole horn. Each blue line represents an individual cow. The thick black line is a smoothed curve fitted to the changes in soft-tissue thickness for all cows. The pink area represents the $95 \%$ confidence interval for the smoothed curve.
(SE): $\pm 0.07, P=0.004]$, from 3.4 to $3.2 \mathrm{~mm}$, corresponding to a $6 \%(\mathrm{SE}: \pm 2.1, P=0.004)$ reduction. We observed an increase in STT (maximum: $+0.8 \mathrm{~mm}$ ) in 10 heifers over the period, but no change or a decrease in STT (maximum: $-1.0 \mathrm{~mm}$ ) in the remaining 24 heifers.

Overall, we found a mean decrease in STT (mean: $-0.6 \mathrm{~mm}, \mathrm{SE}: \pm 0.08, P<0.01)$ at site 2 in the days around calving, and 29 of the heifers had a thinner STT (maximum: $-1.3 \mathrm{~mm}$ ) after calving than before. However, 5 heifers had a thicker STT after calving

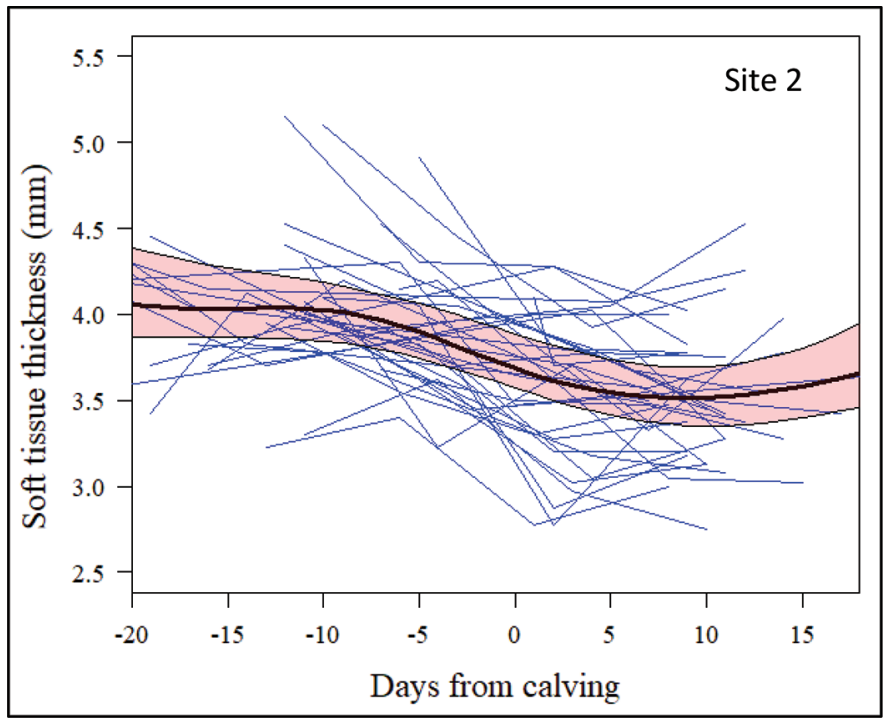

Figure 3. Changes in the mean sole soft-tissue thickness of all 4 hind digits from 34 Holstein heifers in the days around calving at site 2 , the posterior part of the sole horn. Each blue line represents an individual cow. The thick black line is a smoothed curve fitted to the changes in soft-tissue thickness for all cows. The pink area represents the $95 \%$ confidence interval for the smoothed curve. 
(maximum: $0.8 \mathrm{~mm}$ ). The smoothed line of the STT in Figure 3 reveals that a decrease started around $10 \mathrm{~d}$ before calving and continued to $5 \mathrm{~d}$ after calving. However, we did not assess this finding statistically because of insufficient of power, so it is only an observation. The average STT measured at the first examination was $4.1 \mathrm{~mm}$ (minimum-maximum: 2.7 to 5.8 ), and it was $3.5 \mathrm{~mm}$ (minimum-maximum: 2.2 to 5.0 ) at the last examination (Table 2), resulting in an overall mean reduction in STT of $-0.6 \mathrm{~mm}$ (minimum-maximum: 0.8 to $-1.3 \mathrm{~mm}$ ), approximately equal to a $15 \%$ (SE: \pm $2.1, P<0.01)$ reduction over the study period. Twentynine heifers had a BCS reduction of 0.25 to 0.5 during the study period, 3 heifers maintained the same BCS, and 2 had a BCS increase of 0.25 . The mean and median BCS at each examination point are displayed in Table 2. The change in BCS in individual heifers from before to after calving is plotted against the change in STT over the same period (Figure 4).

\section{Analytical Results}

The resulting mixed model included the explanatory variables "days from calving" and "soft-tissue thickness." At site 1, the model predicted a daily STT reduction of $-0.006 \mathrm{~mm}(\mathrm{SE}: \pm 0.002, P=0.03)$ during

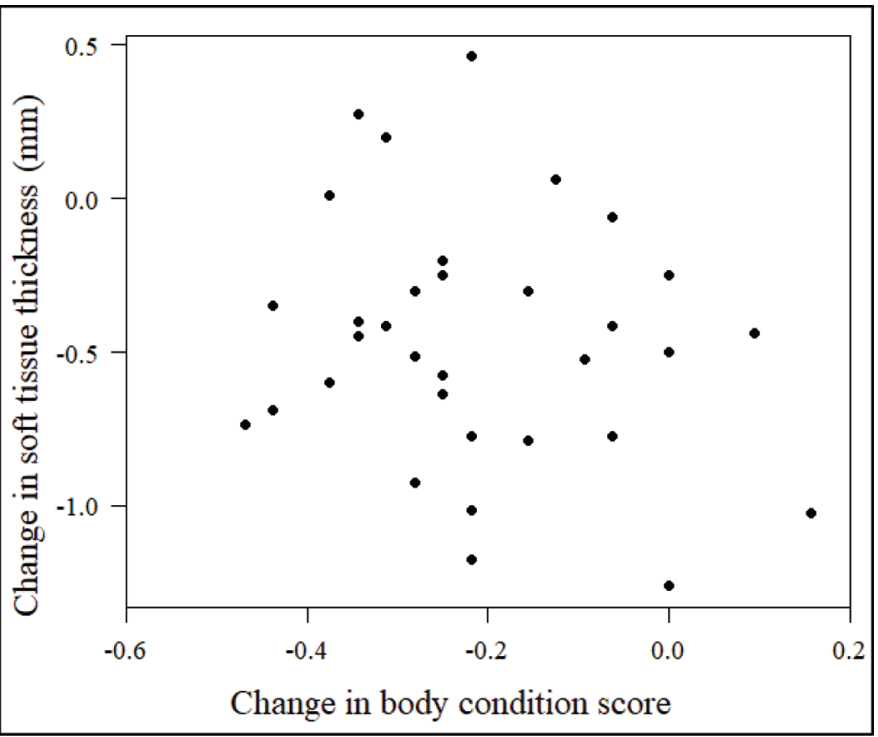

Figure 4. Relationship between change in BCS (categorical scale of 1 to 5 with 0.25 increments) and change in soft tissue thickness from before to after calving. Each dot represents an individual heifer. The $\mathrm{x}$-axis represents the difference in BCS before and after calving. The $\mathrm{y}$-axis represents the difference in the mean soft tissue thickness for the 4 hind digits at site 2, the posterior part of the sole horn, measured before and after calving. the period as an effect of days from calving, with an intercept at $3.3 \mathrm{~mm}(\mathrm{SE}: \pm 0.05, P<0.01)$ at calving. The correlation between days from calving and STT was -0.084 .

At site 2 , a reduction of $0.02 \mathrm{~mm}(\mathrm{SE}: \pm 0.04, P<$ $0.01)$ per day from calving, with an intercept at 3.7 $\mathrm{mm}$ (SE: $\pm 0.05, P<0.01$ ) at calving was predicted. The correlation between days from calving and STT at site 2 was 0.138 . Visual inspection of the standardized within-group residual Q-Q plot showed a normal distribution, which satisfied the assumption of homogeneityof-variance at both sites. We assessed for a quadratic effect of time, but we did not find one $(P=0.33)$.

We did not observe any correlation between change in BCS and STT when comparing findings before and after calving $\left(P=0.27, \mathrm{R}^{2}=0.008\right.$; Figure 4$)$.

The intrarater reliability of the repeated BCS was estimated to be $\kappa=0.45$ (i.e., moderate agreement; Landis and Koch, 1977), based on the exact score values provided by the observer. If we interpreted scores with a maximum difference of 0.25 as being equal, then the $\kappa$ value was an almost perfect score $(\kappa=0.93$; Landis and Koch, 1977).

\section{DISCUSSION}

To our knowledge, this was the first longitudinal study to measure the STT of weight-bearing claws in heifers in the weeks around calving. The 4 measurements we made in the weeks around calving demonstrated a negative association between days from calving and STT. The mean decrease in STT was 15\% (SE: \pm 2.1 , $P<0.01)$ from $10 \mathrm{~d}$ before to $5 \mathrm{~d}$ after calving at site 2 . At site 1, we observed a minor STT decrease of $6 \%$ (SE: $\pm 2.1, P=0.004$ ) over the study period. This finding could indicate that the tip of the distal phalanx was firmly fixed in the collagen structures of the lamella, and the laxity is seen primarily in the structure supporting the caudal part of the distal phalanx. The bone then rotates backward rather than sinking, and the decrease in thickness is mainly due to a compression of the soft tissue measured at site 2 but not at site 1 .

Similar observations were made in a study by Newsome et al. (2017a), in which STT was examined and measured using ultrasound 5 times over a full production cycle, starting 8 wk before calving and ending 29 wk after calving. In this study on elevated claws, STT under the tuberculum flexorum was thinnest 1 wk after calving. However, the authors did not measure STT in the weeks before calving: only before the dry period and 1 wk after calving. Therefore, this study could not explain if the decrease in STT observed from $8 \mathrm{wk}$ before calving to 1 wk after calving occurred over the 
entire dry period or only in the days or weeks around calving.

Our results also support those of Tarlton et al. (2002), who demonstrated that the suspensory connective tissue was relaxed in the days around calving. They focused on the connective tissue in the lamellar part of the wall and showed that the lamellae were more flexible in the week after calving compared with 2 wk before calving. They suggested that calving hormones (e.g., bovine relaxin-like factors and estrogen) would soften the connective tissue in the lamellae, and this could lead to a sinking of the distal phalanx when the cow bears weight on the claw. Our observations were comparable, because the reduction in STT began before calving and continued some days after, and we believe that parturition was the main risk factor for the sinking of the distal phalanx during this period.

The reduction we measured in this study was in static weight-bearing claws on standing animals, but if the compression of the soft tissue was due to the increased elasticity of the connective tissue surrounding the digital cushion fat pads and in the lamella, then we believe the compression may be even more pronounced when the heifer is walking. An increased weight load will affect the weight-bearing claws - in particular the lateral claw - to a greater extent during motion than when a cow is standing on both hind legs (Nuss et al., 2019). Likewise, a greater force will affect the lifted foot when it hits the ground at the end of the stride. The risk of the distal phalanx compressing the soft tissue and damaging the corium due to increased weight load is therefore presumably higher when the cow is standing and walking during the weeks after parturition. Calving is a natural event in the life cycle of the cow, and it should generally not lead to the development of CHDL. However, time budget, handling, and feeding often change significantly for cows and heifers in the days after calving. Several hours are spent standing at the feed table, in the collecting yard, and in the milking parlor, and before calving they spend their time only resting and eating. Veterinary treatments, fresh cow checks, and heat stress in summer could likewise lead to increased standing time. Neave et al. (2017) showed that heifers' lying time decreased from $11.6 \mathrm{~h} / \mathrm{d}(\mathrm{SE} \pm$ 0.6) 2 wk prepartum to $9.1 \mathrm{~h} / \mathrm{d}(\mathrm{SE} \pm 0.6) 1 \mathrm{wk}$ after calving. This was approximately a $22 \%$ reduction in lying time within 3 wk.

When these risk factors are added to the fact that the suspensory apparatus and supporting tissues are less supportive, it could result in inexpedient movement of the distal phalanx, resulting in damage of the corium in the sole, development of claw horn lesions, and lameness (Cook et al., 2004b; Cook et al., 2007). We suggest that the increased incidence of lameness and lesions observed during early lactation as reported in other studies (Leach et al., 1997; Green et al., 2002) is due to a combination of increased movement of the distal phalanx in the weeks around calving and risk factors such as cubicle design (Cook et al., 2004a; Knott et al., 2007), flooring (Bergsten and Frank, 1996), and a loss of body condition (Bicalho et al., 2009; Hoedemaker et al., 2009) in the weeks postpartum.

Studies have demonstrated that a decrease in BCS affects the thickness of the digital cushion (Bicalho et al., 2009; Newsome et al., 2017a), and we observed a decrease in BCS of 0.25 to 0.5 during the same period that STT was reduced. However, we observed no correlation between a decrease in BCS and a reduction in STT. The loss of body condition was comparable to the loss described by Hoedemaker et al. (2009) and Çolakoğlu et al. (2019) over the same period. The heifers continued to lose body condition throughout the study period after calving, whereas the decrease in STT ended around $5 \mathrm{~d}$ after calving, which could indicate a weak association between STT and BCS in the days around calving compared to what other studies have found later in the lactation period (Bicalho et al., 2009; Newsome et al., 2017a). Small changes in BCS $(<0.5)$ might also be explained by imperfect intrarater reliability of BCS, and may not reflect a true difference. Because we used ultrasonography to examine the claws, it might have been easier and more accurate to use ultrasonography to measure the back-fat tissue, as described by Newsome et al. (2017a), but we were not aware of this method when the study was conducted. However, Newsome et al. (2017a) did not find back-fat thickness to be positively correlated with STT $1 \mathrm{wk}$ after calving, so we believe that laxity of the suspensory apparatus is the main factor affecting STT. A change in BCS around calving will have only a minor effect on STT.

Several challenges are related to ultrasound scanning on a weight-bearing claw through a polyethylene plate. First, it is not possible to precisely determine the location of the transducer relative to the claw horn, and the location is based mainly on what can be seen on the ultrasonographic image. Therefore, the transducer was placed beneath the tuberculum flexorum every time, but not necessarily at the same point between the axial and abaxial wall at every measurement. This would have affected the results and might explain some of the STT variation we observed between the heifers, but we believe the effect was random and did not substantially affect the overall results of the study.

Another challenge is to ensure that the heifer distributes weight evenly between both hind legs. Although 
we determined through visual inspection that the heifers bore weight on both hind legs, it was not possible to assess whether they were shifting just a little of their weight from one leg to the other. This could perhaps be solved by lifting the opposite hind leg and scanning a fully loaded claw. However, it might then be necessary to use the belly band in the trim chute to prevent the heifer from falling, and it would then be difficult to control how much weight was carried by the hind leg. Another solution could be to induce a horizontal force manually applied at the location of the hip joint of the opposite leg, as described by Nuss et al. (2019). This would be a feasible method and would ensure that the scans were done on weight-bearing claws. We are not aware of a biologically reasonable explanation for STT to increase during the period around calving. Therefore, we believe that the increase in STT from the first to the last examination point can be explained primarily by a variation in measuring method.

As described by Bach et al. (2019), a constant level of distortion affects the ultrasound images when measurements are made through the bottom of a polyethylene tub on which the hind claws stand. The effect is that structures appear to be approximately $25 \%$ smaller on the images than in reality. This should not affect the proportion of change in the thickness of the soft tissue, but it does affect the actual thickness, meaning that it is more challenging to make comparisons with other studies that describe STT using ultrasonography (Kofler et al., 1999; van Amstel et al., 2004; Bicalho et al., 2009; Toholj et al., 2014; Newsome et al., 2017a, b). Other studies have described ultrasonographic measurements of STT to be smaller than anatomical or computed tomographic measurements of the same structure (Cecen et al., 2015; Tsuka et al., 2019). In particular, when the sole horn thickness increases from less than 5 to greater than $10 \mathrm{~mm}$, the ultrasonographic measurements seem to be proportionally smaller than anatomical and computed tomographic measurements (Bach et al., 2019; Tsuka et al., 2019). In our study, we know that the polyethylene base of the tub had a constant thickness of $10 \mathrm{~mm}$, affecting the measurements by the same factor. However, sole horn thickness is most likely to differ among animals, and it might have affected the variations in STT measured in the animals included in the study.

\section{CONCLUSIONS}

This longitudinal study on 34 Holstein heifers found that sole STT in the posterior part of the sole horn decreased by approximately $15 \%(-0.6 \mathrm{~mm}$; range: 0.8 to $-1.3 \mathrm{~mm}$ ) in the $3 \mathrm{wk}$ around calving. However, the differences ranged from apparent increases in STT to decreases of up to $31 \%$. We found a negative correlation of -0.138 between STT and days from calving at site 2 of the claw. The reduction started at around 10 $\mathrm{d}$ before calving and continued until around $5 \mathrm{~d}$ after calving. We observed a minor reduction of $6 \%(-0.2$ $\mathrm{mm}$; range: 0.8 to $-0.9 \mathrm{~mm}$ ) in STT in the apical part of the sole horn. However, in this area, the differences also ranged from an apparent increase to a decrease of $29 \%$. We conclude that the distal phalanx was sinking mainly in the heel area and rotating backward toward the posterior part of the sole. We did not observe a major increase in STT in the weeks after calving, and we did not find any correlation between BCS and STT.

\section{ACKNOWLEDGMENTS}

The authors acknowledge Helle Holstein I/S (Varde, Denmark) and the herd owner Morten Wenzel for his assistance, patience, and time. They also thank Anders Ring for helping to move the heifers into the chute and for collecting some of the data. The authors declare no competing interests.

\section{REFERENCES}

Bach, K., S. S. Nielsen, A. M. Danscher, and N. Capion. 2019. Ultrasonographical examination of bovine claws through the sole horn on weight-bearing claws. J Dairy Sci 102:4364-4375. https://doi.org/ 10.3168/jds.2018-14803.

Bergsten, C., and B. Frank. 1996. Sole haemorrhages in tied primiparous cows as an indicator of periparturient laminitis: Effects of diet, flooring and season. Acta Vet. Scand. 37:383-394.

Bergsten, C., and A. H. Herlin. 1996. Sole haemorrhages and heel horn erosion in dairy cows: The influence of housing system on their prevalence and severity. Acta Vet. Scand. 37:395-408.

Bergsten, C., E. Telezhenko, and M. Ventorp. 2015. Influence of soft or hard floors before and after first calving on dairy heifer locomotion, claw and leg health. Animals (Basel) 5:662-686. https://doi .org/10.3390/ani5030378.

Bicalho, R. C., V. S. Machado, and L. S. Caixeta. 2009. Lameness in dairy cattle: A debilitating disease or a disease of debilitated cattle? A cross-sectional study of lameness prevalence and thickness of the digital cushion. J. Dairy Sci. 92:3175-3184. https://doi .org/10.3168/jds.2008-1827.

Bicalho, R. C., F. Vokey, H. N. Erb, and C. L. Guard. 2007. Visual locomotion scoring in the first seventy days in milk: Impact on pregnancy and survival. J. Dairy Sci. 90:4586-4591. https://doi .org/10.3168/jds.2007-0297.

Booth, C. J., L. D. Warnick, Y. T. Gröhn, D. O. Maizon, C. L. Guard, and D. Janssen. 2004. Effect of lameness on culling in dairy cows. J. Dairy Sci. 87:4115-4122. https://doi.org/10.3168/jds.S0022 -0302(04)73554-7.

Bruijnis, M. R. N., B. Beerda, H. Hogeveen, and E. N. Stassen. 2012. Assessing the welfare impact of foot disorders in dairy cattle by a modeling approach. Animal 6:962-970. https://doi.org/10.1017/ S1751731111002606.

Capion, N., S. M. Thamsborg, and C. Enevoldsen. 2008. Prevalence of foot lesions in Danish Holstein cows. Vet. Rec. 163:80-86. https:// doi.org/10.1136/vr.163.3.80.

Cecen, G., H. Salci, D. S. Intas, N. Celimli, and G. U. Caliskan. 2015. Ultrasonographic and macroscopic comparison of the thickness of 
the capsule, corium, and soft tissues in bovine claws: An in vitro study. J. Vet. Sci. 16:107-112. https://doi.org/10.4142/jvs.2015.16 .1 .107 .

Çolakoğlu, H. E., M. O. Yazlık, M. Pekcan, U. Kaya, C. Kaçar, M. R. Vural, S. Kurt, M. M. Yildirim, A. Bas, and Ş. Küplülü. 2019. Impact of prepartum body condition score loss on metabolic status during the transition period and subsequent fertility in Brown Swiss dairy cows. J. Vet. Res. 63:375-382. https://doi.org/10 .2478/jvetres-2019-0039.

Cook, N. B., T. B. Bennett, and K. V. Nordlund. 2004a. Effect of free stall surface on daily activity patterns in dairy cows with relevance to lameness prevalence. J. Dairy Sci. 87:2912-2922. https://doi .org/10.3168/jds.S0022-0302(04)73422-0.

Cook, N. B., R. L. Mentink, T. B. Bennett, and K. Burgi. 2007. The effect of heat stress and lameness on time budgets of lactating dairy cows. J. Dairy Sci. 90:1674-1682. https://doi.org/10.3168/ jds.2006-634.

Cook, N. B., K. V. Nordlund, and G. R. Oetzel. 2004b. Environmental influences on claw horn lesions associated with laminitis and subacute ruminal acidosis in dairy cows. J Dairy Sci 87(Suppl.):E36E46. https://doi.org/10.3168/jds.S0022-0302(04)70059-4.

Edmonson, A. J., I. J. Lean, L. D. Weaver, T. Farver, and G. Webster. 1989. A body condition scoring chart for Holstein dairy cows. J. Dairy Sci. 72:68-78. https://doi.org/10.3168/jds.S0022 -0302(89)79081-0.

Ettema, J. F., N. Capion, and A. E. Hill. 2007. The association of hoof lesions at claw trimming with test-day milk yield in Danish Holsteins. Prev. Vet. Med. 79:224-243. https://doi.org/10.1016/j .prevetmed.2006.12.007.

Fabian, J., R. A. Laven, and H. R. Whay. 2014. The prevalence of lameness on New Zealand dairy farms: A comparison of farmer estimate and locomotion scoring. Vet. J. 201:31-38. https://doi .org/10.1016/j.tvjl.2014.05.011.

Fritzböger, E., and H. H. Smedegaard. 1962. Klovens Beskaering. Pages 148-155 Kvaegets Klovpleje. 2nd ed. Carl Fr. Mortensen, ed. Veterinaermedicinsk bog-og instrumenthandel, Copenhagen, Denmark.

Garbarino, E. J., J. A. Hernandez, J. K. Shearer, C. A. Risco, and W. W. Thatcher. 2004. Effect of lameness on ovarian activity in postpartum Holstein cows. J. Dairy Sci. 87:4123-4131. https://doi .org/10.3168/jds.S0022-0302(04)73555-9.

Green, L. E., V. J. Hedges, Y. H. Schukken, R. W. Blowey, and A. J. Packington. 2002. The impact of clinical lameness on the milk yield of dairy cows. J. Dairy Sci. 85:2250-2256. https://doi.org/10 .3168/jds.S0022-0302(02)74304-X.

Green, L. E., J. N. Huxley, C. Banks, and M. J. Green. 2014. Temporal associations between low body condition, lameness and milk yield in a UK dairy herd. Prev. Vet. Med. 113:63-71. https://doi.org/10 .1016/j.prevetmed.2013.10.009.

Hoedemaker, M., D. Prange, and Y. Gundelach. 2009. Body condition change ante- and postpartum, health and reproductive performance in German Holstein cows. Reprod. Domest. Anim. 44:167173. https://doi.org/10.1111/j.1439-0531.2007.00992.x.

Knott, L., J. F. Tarlton, H. Craft, and A. J. Webster. 2007. Effects of housing, parturition and diet change on the biochemistry and biomechanics of the support structures of the hoof of dairy heifers. Vet. J. 174:277-287. https://doi.org/10.1016/j.tvj1.2006.09.007.

Kofler, J., P. Kubber, and W. Henninger. 1999. Ultrasonographic imaging and thickness measurement of the sole horn and the underlying soft tissue layer in bovine claws. Vet. J. 157:322-331. https:// doi.org/10.1053/tvjl.1998.0315.

Landis, J. R., and G. G. Koch. 1977. The measurement of observer agreement for categorical data. Biometrics 33:159-174. https://doi .org/10.2307/2529310.

Leach, K. A., D. N. Logue, S. A. Kempson, J. E. Offer, H. E. Ternent, and J. M. Randall. 1997. Claw lesions in dairy cattle: Development of sole and white line haemorrhages during the first lactation. Vet. J. 154:215-225. https://doi.org/10.1016/s1090-0233(97)80024 -https://doi.org/x.
Lim, P. Y., J. N. Huxley, J. A. Willshire, M. J. Green, A. R. Othman, and J. Kaler. 2015. Unravelling the temporal association between lameness and body condition score in dairy cattle using a multistate modelling approach. Prev. Vet. Med. 118:370-377. https:// doi.org/10.1016/j.prevetmed.2014.12.015.

Lischer, C. J., P. Ossent, M. Raber, and H. Geyer. 2002. Suspensory structures and supporting tissues of the third phalanx of cows and their relevance to the development of typical sole ulcers (Rusterholz ulcers). Vet. Rec. 151:694-698. https://doi.org/10.1136/vr .151.23.694.

Machado, V. S., L. S. Caixeta, J. A. McArt, and R. C. Bicalho. 2010. The effect of claw horn disruption lesions and body condition score at dry-off on survivability, reproductive performance, and milk production in the subsequent lactation. J. Dairy Sci. 93:4071-4078. https://doi.org/10.3168/jds.2010-3177.

Neave, H. W., J. Lomb, M. A. G. von Keyserlingk, A. Behnam-Shabahang, and D. M. Weary. 2017. Parity differences in the behavior of transition dairy cows. J. Dairy Sci. 100:548-561. https://doi.org/ 10.3168/jds.2016-10987.

Newsome, R. F., M. J. Green, N. J. Bell, N. J. Bollard, C. S. Mason, H. R. Whay, and J. N. Huxley. 2017a. A prospective cohort study of digital cushion and corium thickness. Part 1: Associations with body condition, lesion incidence, and proximity to calving. J. Dairy Sci. 100:4745-4758. https://doi.org/10.3168/jds.2016-12012.

Newsome, R. F., M. J. Green, N. J. Bell, N. J. Bollard, C. S. Mason, H. R. Whay, and J. N. Huxley. 2017b. A prospective cohort study of digital cushion and corium thickness. Part 2: Does thinning of the digital cushion and corium lead to lameness and claw horn disruption lesions? J. Dairy Sci. 100:4759-4771. https://doi.org/ 10.3168/jds.2016-12013.

Nuss, K., J. Muller, and T. Wiestner. 2019. Effects of induced weight shift in the hind limbs on claw loads in dairy cows. J. Dairy Sci. 102:6431-6441. https://doi.org/10.3168/jds.2018-15539.

Ossent, P., and C. Lischer. 1998. Bovine laminitis: The lesions and their pathogenesis. In Pract. 20:415-427. https://doi.org/10.1136/ inpract.20.8.415.

Pinheiro, J., D. Bates, S. DebRoy, D. Sarkar, R Core Team. 2019. nlme: Linear and nonlinear mixed effects models. $\mathrm{R}$ package version 3.1-140. Accessed Jan. 11, 2021. https://CRAN.R-project .org $/$ package $=$ nlme

Räber, M., C. J. Lischer, H. Geyer, and P. Ossent. 2004. The bovine digital cushion - a descriptive anatomical study. Vet. J. 167:258 264. https://doi.org/10.1016/S1090-0233(03)00053-4.

Randall, L. V., M. J. Green, M. G. G. Chagunda, C. Mason, S. C. Archer, L. E. Green, and J. N. Huxley. 2015. Low body condition predisposes cattle to lameness: An 8-year study of one dairy herd. J. Dairy Sci. 98:3766-3777. https://doi.org/10.3168/jds.2014-8863.

Tarlton, J. F., D. E. Holah, K. M. Evans, S. Jones, G. R. Pearson, and A. J. F. Webster. 2002. Biomechanical and histopathological changes in the support structures of bovine hooves around the time of first calving. Vet. J. 163:196-204. https://doi.org/10.1053/tvjl .2001 .0651 .

Thomsen, P. T., L. Munksgaard, and J. T. Sorensen. 2012. Locomotion scores and lying behaviour are indicators of hoof lesions in dairy cows. Vet. J. 193:644-647. https://doi.org/10.1016/j.tvjl .2012.06.046.

Toholj, B., M. Cincovic, M. Stevancevic, J. Spasojevic, V. Ivetic, and A. Potkonjak. 2013. Evaluation of ultrasonography for measuring solar soft tissue thickness as a predictor of sole ulcer formation in Holstein-Friesian dairy cows. Vet. J. 199:290-294. https://doi.org/ 10.1016/j.tvjl.2013.11.005.

Tsuka, T., R. Nishimura, M. Hishinuma, Y. Murahata, M. Yamashita, K. Azuma, T. Osaki, N. Ito, Y. Okamoto, and T. Imagawa. 2019. Reliability of ultrasonographic measurements of bovine sole structures in relation to sole horn thickness, measured by computed tomography, and sole horn hardness. J. Dairy Sci. 102:10105-10118. https://doi.org/10.3168/jds.2018-15175.

van Amstel, S. R., F. L. Palin, and J. K. Shearer. 2004. Measurement of the thickness of the corium and subcutaneous tissue of the hind 
claws of dairy cattle by ultrasound. Vet. Rec. 155:630-633. https:/ /doi.org/10.1136/vr.155.20.630.

Vermunt, J. J., and P. R. Greenough. 1996. Sole haemorrhages in dairy heifers managed under different underfoot and environmental conditions. Br. Vet. J. 152:57-73. https://doi.org/10.1016/ s0007-1935(96)80086-8.

von Keyserlingk, M. A. G., A. Barrientos, K. Ito, E. Galo, and D. M. Weary. 2012. Benchmarking cow comfort on North American freestall dairies: Lameness, leg injuries, lying time, facility design, and management for high-producing Holstein dairy cows. J. Dairy Sci. 95:7399-7408. https://doi.org/10.3168/jds.2012-5807.

Warnick, L. D., D. Janssen, C. L. Guard, and Y. T. Grohn. 2001. The effect of lameness on milk production in dairy cows. J. Dairy Sci. 84:1988-1997. https://doi.org/10.3168/jds.S0022-0302(01)74642 $-5$

Welfare Quality. 2009. Welfare Quality Assessment Protocol for Cattle. Welfare Quality Consortium, Lelystad, the Netherlands.

Whay, H. R., D. C. J. Main, L. E. Green, and A. J. F. Webster. 2003. Assessment of the welfare of dairy cattle using animal-based mea- surements: Direct observations and investigation of farm records. Vet. Rec. 153:197-202. https://doi.org/10.1136/vr.153.7.197.

Wickham, H., M. Averick, J. Bryan, W. Chang, L. D'Agostino McGowan, R. François, G. Grolemund, A. Hayes, L. Henry, J. Hester,

M. Kuhn, T. Lin Pedersen, E. Miller, S. Milton Bache, K. Müller,

J. Ooms, D. Robinson, D. Page Seidel, V. Spinu, K. Takahashi,

D. Vaughan, C. Wilke, K. Woo, and H. Yutani. 2019. Welcome to the tidyverse. J. Open Source Softw. 4:1686. https://doi.org/10 .21105 /joss. 01686 .

\section{ORCIDS}

K. Bach ๑ https://orcid.org/0000-0001-5718-2069

S. S. Nielsen (ㄷ) https://orcid.org/0000-0003-2417-0787

N. Capion ๑ https://orcid.org/0000-0001-8278-9321 